\title{
ID NON CULPAM, SED POENAM ESSE IUDICABAM (CONFESSIONES VII 3, 5). NIEKTÓRE WĄTPLIWOŚCI I REFLEKSJE ŚW. AUGUSTYNA ANALIZUJĄCEGO ŹRÓDLO ZLA
}

Św. Augustyn pisząc Wyznania próbował odpowiedzieć na wiele egzystencjalnych pytań, rozważając osobiste doświadczenie oraz biorąc pod uwagę duchowe dobro swoich czytelników, przeżywających podobne rozterki i wątpliwości. Temat zła jest niewątpliwie jednym z zasadniczych zagadnień, jakie przewijają się na kartach dzieła św. Augustyna, który - opisując historię swojego życia i popełnione błędy - zajmował się też kwestiami filozoficznymi typu: Skąd się bierze zło? Jakie jest jego znaczenie? Czy i gdzie jest nasza wina?

Są to pytania bardzo obszerne i nie zamierzam tutaj wchodzić w złożone rozważania dotyczące tych ciągle aktualnych tematów ${ }^{1}$. Chciałbym natomiast zaproponować analizę jednego z najważniejszych fragmentów Wyznań dotyczących wspomnianych kwestii, by ukazać niektóre refleksje i wątpliwości św. Augustyna poszukującego źródła zła. Chodzi o tekst, który w krytycznym wydaniu NBA oznaczony jest podtytułem Liberum voluntatis arbitrium est causa mali (VII 3, 4-5). Następnie zamierzam, w świetle tego fragmentu, przedstawić ocenę moralną, jaką św. Augustyn daje w tym samym dziele w odniesieniu do swoich relacji z kobietą bezimienną.

1. W poszukiwaniu przyczyny zła. Św. Augustyn zwraca się do Boga, któremu wyznaje po wielu latach przeżywane w przeszłości trudności dotyczące znalezienia przyczyny zła:

„Ale chociaż mówiłem i mocno wierzyłem, że Ty, Panie nasz, Boże prawdziwy, który nie tylko nasze dusze, lecz także ciała stworzyłeś, i nie tylko

${ }^{*}$ Ks. dr hab. Waldemar Turek - professore invitato na Pontificia Università Urbaniana w Rzymie, pracownik Sekretariatu Stanu Stolicy Apostolskiej; e-mail: turek@tiscalinet.it.

${ }^{1}$ Jako ogólne wprowadzenie do tematu zła u św. Augustyna odsyłam do opracowania G.R. Evans, Male, w: Agostino. Dizionario enciclopedico, ed. A. Fitzgerald, ed. italiana a cura di L. Alici e A. Pieretti, Roma 2007, 882-888. Autor już na początku prezentacji zauważa, że zagadnienie to pojawia się w różnym stopniu i w różnych kontekstach niemal we wszystkich dziełach św. Augustyna: „Il resoconto agostiniano del problema del male giunse alla fine ad abbracciare quasi tutti i settori dei suoi scritti, nella misura in cui percepì sempre di più le ramificazioni della materia" (tamże, s. 882). 
dusze i ciała nasze, lecz wszystkie rzeczy ożywione i nieożywione - jesteś niepokalany i niezmienny, nie mogłem znaleźć wyraźnego, niewątpliwego wyjaśnienia przyczyny zła (causa mali)"’2.

Warto zwrócić najpierw uwagę na niektóre ważniejsze terminy pojawiające się w tym fragmencie Wyznań św. Augustyna. W odniesieniu do Boga używa on kilku charakterystycznych przymiotników: incontaminabilis, inconvertibilis, nulla ex parte mutabilis, verus, znaczących zwłaszcza w kontekście polemiki antymanichejskiej. U manichejczyków problem zła rozwiązywano przyjmując dualizm, wedle którego istnieją dwie zasady odwieczne i wzajemnie przeciwstawne. Św. Augustyn dał się zwieźć tej teorii i - przynajmniej przez pewien czas - akceptował tego typu rozwiązanie. W jego przypadku działo się to jednak bardziej na płaszczyźnie emocji niż intelektu. W Wyznaniach celowo używa wyżej wymienionych i innych przymiotników w odniesieniu do Boga, ukazujących i opisujących jedną Zasadę, odrzucając w ten sposób pogląd manichejczyków.

W przytoczonym tekście św. Augustyna nie może nam umknąć wyraźne stwierdzenie, wedle którego Bóg jest Stworzycielem wszystkiego: bytów ożywionych i nieożywionych. Po tym zdaniu św. Augustyn przyznaje, że nie potrafił wyjaśnić, skąd się wzięło zło, skoro wszystko zostało powołane do życia przez prawdziwego Boga, a Bóg jako absolutnie dobry nie mógł stworzyć zła ${ }^{3}$.

Teoretyczne rozważania i poszukiwania św. Augustyna przeplatały się z doświadczeniem codziennego życia i baczną obserwacją postępowania innych ludzi, a zwłaszcza manichejczyków.

„Spokojnie prowadziłem dalsze badania, upewniwszy się, że teorie manichejczyków są fałszywe. Całe moje serce buntowało się przeciwko tym ludziom, bo widziałem, że poszukując przyczyny zła, sami byli napełnieni złem. Woleli bowiem uznać, że Twoja substancja doznaje zła, niż przyznać, że ich ludzka substancja zło popełnia"4.

2. Przyczyna czynienia zła i przyczyna doznawania zła. W sytuacji ciągłej niepewności i niekończących się poszukiwań św. Augustyn, rozważa-

${ }^{2}$ Augustinus, Confessiones VII 3, 4, ed. A. Trapè - C. Carena, NBA 1, Roma 19915, 182: „Sed et ego adhuc, quamvis incontaminabilem et inconvertibilem et nulla ex parte mutabilem dicerem firmeque sentirem Deum nostrum, Deum verum, qui fecisti non solum animas nostras sed etiam corpora, nec tantum nostras animas et corpora, sed omnes et omnia, non tenebam explicitam et enodatam causam mali”, tłum. Z. Kubiak: Święty Augustyn, Wyznania, Kraków 2008, 181.

${ }^{3}$ Evans (Male, s. 883) wyjaśnia: „Il paradosso centrale del problema del male si può riassumere in poche parole. [...]. O dobbiamo dire che Dio non è completamente buono e che permette il male o che ne è persino l'autore. $\mathrm{O}$ dobbiamo dire che Dio non è onnipotente, e sebbene sia completamente buono e impedirebbe il male se potesse, non ha mezzi per fermarlo".

${ }^{4}$ Augustinus, Confessiones VII 3, 4, NBA 1, 182: „Itaque securus eam quaerebam et certus non esse verum quo illi dicerent, quo toto animo fugiebam, quia videbam quaerendo, unde malum, repletos malitia, qua opinarentur tuam potius substantiam male pati quam suam male facere", thum. Kubiak, s. 181. 
jąc przede wszystkim swoją wolę, zaczął rozróżniać przyczynę czynienia zła i przyczynę doznawania zła:

„Usiłowałem więc pojąć to, co mi mówiono: że przyczyną czynienia zła jest wybór dokonywany przez naszą wolną wolę, a przyczyną doznawania zła jest Twój sprawiedliwy wyrok. Nie mogłem jeszcze tego zrozumieć z zupełną jasnością"5.

Na podstawie tych zdań można mówić o złu czynionym i o złu doznawanym: pierwsze jest konsekwencją naszego wyboru (culpa), drugie natomiast łączy się z wyrokiem Boga, wydanym po tym jak człowiek dokonał niewłaściwego wyboru (poena).

Tego typu interpretacja zadawalała św. Augustyna jednak jedynie do pewnego stopnia:

„Ilekroć czegokolwiek chciałem albo nie chciałem, byłem całkowicie pewny, że to właśnie ja - a nie kto inny - chcę tego albo nie chcę. I już zaczynało mi świtać, że właśnie w woli jest źródło mego grzechu. Ilekroć bowiem czyniłem coś mimowolnie, odczuwałem, że raczej doznaję, niż czynię; a to, czego doznawałem, uważałem nie za winę (culpam), lecz za karę (poenam). Ponieważ zaś uznawałem Ciebie za sprawiedliwego, natychmiast stwierdzałem w duchu, że słusznie odbieram chłostę"

Rodziło się jednak, prawie spontanicznie, kolejne pytanie:

„Kto mnie stworzył? Czyż nie Bóg mój, który nie tylko jest dobry, lecz jest dobrem samym? Skądże więc we mnie to pragnienie zła i opór wobec dobra, którymi zasługuję na sprawiedliwą karę? Kto to we mnie wszczepił? Kto we mnie zasiał to gorzkie ziarno, skoro mnie całego stworzył najukochańszy Bóg mój?"’.

Koncepcja zła, zarówno w sensie culpa jak i w sensie poena, nie była do pogodzenia w myśli św. Augustyna z koncepcją Boga dobrego, określanego właśnie jako ipsum bonum ${ }^{8}$. Dlaczego pojawia się zło w nas, którzy jesteśmy

${ }^{5}$ Tamże VII 3, 5, NBA 1, 182: „Et intendebam, ut cernerem quo audiebam, liberum voluntatis arbitrium causam esse, ut male faceremus et rectum iudicium tuum ut pateremur, et eam liquidam cerenere non valebam", thum. Kubiak, s. 181.

${ }^{6}$ Tamże: „Itaque cum aliquid vellem aut nollem, non alium quam me velle ac nolle certissimus eram et ibi esse causam peccati mei iam iamque animadvertebam. Quo autem invitus facerem, pati me potius quam facere videbam et id non culpam, sed poenam esse iudicabam, qua me non iniuste plecti te iustum cogitans cito fatebar", thum. Kubiak, s. 181-182.

${ }^{7}$ Tamże VII 3, 5, NBA 1, 183-184: „Quis fecit me? Nonne Deus meus, non tantum bonus, sed ipsum bonum? Unde igitur mihi male velle et bene nolle? Ut esset, cur iuste poenas luerem? Quis in me hoc posuit et insevit mihi plantarium amaritudinis, cum totus fierem a dulcissimo Deo meo?", tłum. Kubiak, s. 182.

${ }^{8}$ Por. J. Wetzel, Colpa, mancanza, w: Agostino. Dizionario enciclopedico, s. 430. Autor opracowania zwraca uwagę na fakt, że mamy do czynienia z terminem złożonym, który umyka łatwemu 
stworzeniami dobrego Boga? Jednej rzeczy św. Augustyn był ciągle pewny:

„Byłem obowiązany szukać Ciebie i starać się o odkrycie źródła zła, czyli o zrozumienie, skąd pochodzi owo zepsucie, które Twojej substancji w żadnym stopniu nie może naruszyć"’.

3. Zło nie jest substancją. Kontynuując swoją refleksję na temat zła, św. Augustyn doszedł do wniosku, że:

„Wszystko, co istnieje, jest dobre. A owo zło, którego pochodzenie chciałem odkryć, nie jest substancją. Gdyby bowiem było substancją, byłoby dobrem. [...] Pojąłem w sposób zupełnie jasny, że wszystko, co stworzyłeś, jest dobre i że nie ma żadnych substancji, których byś nie stworzył"10.

Z przytoczonych tekstów św. Augustyna jasno wynika, że zło metafizyczne, moralne i fizyczne, nie jest substancją a jedynie brakiem dobra. Zło metafizyczne jest związane z ograniczeniami dotyczącymi stworzeń; zło moralne jest owocem nieuporządkowanego używania wolności; zło fizyczne jest konsekwencją i słuszną karą za poniesione winy ${ }^{11}$.

Idea zła rozumianego jako konsekwencja naszego wyboru i zła jako kary za nasze niewłaściwe postępowanie przewija się w różnych miejscach Wyznań św. Augustyna, który w księdze dziesiątej podsumowuje:

„Niech się moimi dobrymi uczynkami uradują, niech westchną nad moimi grzechami. To, co dobre, Ty czynisz we mnie: $z$ Twojej to pochodzi łaski. Co złe, jest moim grzechem i karą przez Ciebie wymierzoną" 12 .

Spróbujmy teraz owo rozróżnienie na culpa i poena zastosować do ważnego epizodu z życia św. Augustyna, tzn. do jego związku z kobietą bezimienną, by odpowiedzieć na pytanie jak św. Augustyn, pisząc Wyznania, postrzegał tę relację od strony moralnej.

opisowi i analizie: „Non vi è percorso di colpa in Agostino, anche nelle Confessioni dove compie sforzi notevoli per evidenziare le proprie inadequatezze personali”.

${ }^{9}$ Augustinus, Confessiones VII 4, 6, NBA 1, 184: „Te quaerere debebam atque inde advertere, ubi sit malum, id est unde sit ipsa corruptio, qua violari substantia tua nullo modo potest", thum. Kubiak, s. 182-183.

${ }^{10}$ Tamże VII 12, 18, NBA 1, 202: „Ergo quaecumque sunt, bona sunt, malumque illud, quod quaerebam unde esset, non est substantia, quia, si substantia esset, bonum esset. [...] Itaque vidi et manifestatum est mihi, quia omnia bona tu fecisti et prorsus nullae substantiae sunt, quae tu non fecisti", thum. Kubiak, s. 196-197.

${ }^{11}$ Por. NBA 1, 183, nota 2.

${ }^{12}$ Augustinus, Confessiones X 4, 5, NBA 1, 302: „Respirent in bonis meis, suspirent in malis meis. Bona mea instituta tua sunt et dona tua, mala mea delicta mea sunt et iudicia tua", thum. Kubiak, s. 280. 
4. Relacja $z$ kobietą bezimienną. Przypomnijmy pewne fakty z życia autora Wyznań. W 371 r., czyli gdy św. Augustyn miał 17 lat, w Kartaginie, w czasie drugiego roku studiów, wziął do swojego domu kobietę, która stała się jego konkubiną. Na temat ich kilkunastoletniego związku napisano wiele, oskarżając zwykle autora Wyznań o wielki błąd swojego młodzieńczego życia.

Dzisiaj próbuje się spojrzeć inaczej na prawie czternaście lat związku dziewczyny bezimiennej ze św. Augustynem. Usprawiedliwienia, jakie podają biografowie św. Augustyna, opierają się na kilku argumentach. Poza oczywistym faktem, że nie był on jeszcze chrześcijaninem, zauważa się, że w wielkim mieście Kartaginie, której mieszkańcy znani byli ze swobody obyczajów, św. Augustyn mógł dokonać jakiegoś innego, jeszcze gorszego z punktu widzenia moralnego, wyboru. Warto dodać, że na związek tego typu pozwalało ówczesne prawo rzymskie: kto nie miał żony, mógł mieć konkubinę.

Św. Augustyn wziął zatem do siebie kobietę, która pozostanie dla nas bez imienia; trzymał ją u siebie mimo trudności ekonomicznych, na jakie niekiedy napotykał, kochał ją i pozostał jej wierny. Chodzi o przypadek dobrowolnego ograniczenia swawoli moralnej; tym bardziej znaczący, jeśli weźmie się pod uwagę sytuację w samej rodzinie św. Augustyna, w której jego ojciec Patrycjusz nie świecił przykładem wierności wobec swojej żony, pobożnej Moniki.

$\mathrm{Z}$ relacji św. Augustyna i kobiety bezimiennej narodził się syn Adeodatus, chłopiec wielkiej dobroci i wyjątkowych zdolności, który swoją inteligencją wzbudzał podziw u św. Augustyna i jego wykształconych znajomych.

Związek św. Augustyna z bezimienną zakończył się w sposób w jakiejś mierze zaskakujący i do dzisiaj nie w pełni wyjaśniony. Troskliwa św. Monika, przewidując rychłe nawrócenie św. Augustyna, zapragnęła, aby się ożenił, przyjął chrzest i zaczął nowe życie według reguł chrześcijańskich. Dlaczego jednak nie wzięto pod uwagę uczciwej, kochającej i wiernej Augustynowi kobiety bezimiennej? Jej miłość była przecież odwzajemniona przez św. Augustyna, o czym świadczy choćby ból, jaki przeżywał on po jej odejściu. Jednak on sam stwierdza w Wyznaniach, że jego towarzyszka życia była przeszkodą do małżeństwa ${ }^{13}$. Dlaczego? - pytamy prawie spontanicznie i odwołujemy się do tekstów św. Augustyna. Nie znajdujemy jednak w nich odpowiedzi. Możemy jedynie snuć domysły, trudne, niepewne i często ryzykowne.

Można zatem brać pod uwagę racje duchowe, ekonomiczne i społeczne. Dwie pierwsze nie znajdują poważniejszych argumentów; wydaje się, że decydującą rolę odegrał kontekst społeczny. Matka Adeodata pochodziła z niskiej klasy społecznej, a w takim przypadku obowiązujące wówczas prawo rzymskie zabraniało legalnego małżeństwa. Wiedziała o tym sama konkubina, która zdecydowała w pewnym momencie, dla dobra św. Augustyna i Adeodata, opuścić ich obydwu, by ułatwić św. Augustynowi zawarcie legalnego związku małżeńskiego i zapewnić godną przyszłość ich dziecku. Sam św. Augustyn dodaje, że bezimienna kobieta postanowiła, by po odejściu nie wiązać

${ }^{13}$ Por. tamże VI 15, 25, NBA 1, 174, tłum. Kubiak, s. 173. 
się już z żadnym innym mężczyzną ${ }^{14}$, co jeszcze bardziej wzbudzało u niego podziw dla niej.

5. Ocena moralna związku $z$ kobietą bezimienną. Interesuje nas teraz osąd moralny, dany przez św. Augustyna w odniesieniu do swojej relacji z kobietą bezimienną. Św. Augustyn pisząc Wyznania, oceniał swoje postępowanie w świetle otrzymanej od Boga łaski i nie mógł pominąc tej stosunkowo długiej historii. Nie mamy jednak ani szczegółowej analizy ani tym bardziej dokładnej oceny moralnej tego związku, co może nas trochę dziwić, skoro autor Wyznań opisuje ze szczegółami wiele wydarzeń ze swojego życia, które z pewnością nie miały tak ważnego dla niego znaczenia.

Wydaje się, że w interesującej nas kwestii najwięcej może powiedzieć nam ten oto tekst Wyznań:

„W owych też latach żyłem z kobietą niezwiązaną ze mną prawnym małżeństwem, na którą natrafiła moja nie kierująca się roztropnością namiętność. Ale miałem tylko tę jedną kobietę i dochowywałem jej wierności. W tym związku mogłem przez własne doświadczenie poznać, jaka jest różnica między prawdziwym małżeństwem, zawieranym w celu wydania na świat potomstwa, a związkiem skojarzonym tylko dla zaspokojenia namiętności, w którym rodzą się dzieci także niechciane - ale gdy się urodziły, to już się je kocha"15.

Przytoczone wyznania pozwalają na wyciągnięcie kilku wniosków. Św. Augustyn wyraźnie podkreśla, że jego związek z nieznaną z imienia kobietą nie miał charakteru małżeństwa prawnego. Oczywiście, ma on tu na uwadze małżeństwo w sensie prawa rzymskiego, a nie chrześcijańskiego. Wyznaje następnie, że związek ten powstał na skutek jego namiętności, natomiast zabrakło mu roztropności. Jest to niezwykle doniosłe stwierdzenie św. Augustyna, który już po nawróceniu poświęci wiele miejsca w swojej posłudze duszpasterskiej i pisarskiej roli roztropności i potrzebie opanowywania namiętności w codziennym życiu chrześcijanina.

Użyty przez św. Augustyna na określenie namiętności rzeczownik ardor może mieć zarówno w języku klasycznym, jak i w samych dziełach św. Augus-

${ }^{14}$ Por. tamże. W przedstawieniu historii relacji św. Augustyna z kobietą bezimienną korzystałem głównie z opracowania A. Trapè, Introduzione, w: NBA 1, LV-LVIII. Na temat powodów, dla których św. Augustyn nie ożenił się z kobietą bezimienną, autor pisze: „Ragioni spirituali, economiche o sociali? Le tre ipotesi sono possibili, e sono state avanzate. Non vedo perché e come potessero entrarci le ragioni spirituali. Non credo, dato l'amore di Agostino per quella donna, che sarebbero state sufficienti le ragioni economiche. Ritengo valida la terza ipotesi: le ragioni sociali" (tamże, s. LVII-LVIII).

${ }^{15}$ Augustinus, Confessiones IV 2, 2, NBA 1, 84: „In illis annis unam habebam non eo quod legitimum vocatur coniugio cognitam, sed quam indagaverat vagus ardor inops prudentiae, sed unam tamen, ei quoque servans tori fidem; in qua sane experirer exemplo meo, quid distaret inter coniugalis placiti modum, quod foederatum esset generandi gratia, et pactum libidinosi amoris, ubi proles etiam contra votum nascitur, quamvis iam nata cogat se diligi”, thum. Kubiak, s. 94. 
tyna, wiele znaczeń, niekoniecznie negatywnych. Jeśli jednak spojrzymy nań pod kątem całego wyrażenia św. Augustyna, czyli vagus ardor inops prudentiae, nietrudno zauważyć, że autor ocenia go w tym wypadku negatywnie. Podobnie czyni to w innych zdaniach Wyznań, w których opisuje namiętności przede wszystkim jako ,przywiązania, zamącenia naszego ducha, ściągające nas w dół poprzez uwikłanie w troskach tego świata" ${ }^{16}$. Gdzie indziej św. Augustyn wyraźnie dodaje, że ulegając namiętnościom, człowiek żyje w ciemnościach ${ }^{17}$.

Św. Augustyn usprawiedliwia się następnie przez fakt, że miał tylko jedną kobietę, której był wierny. Można zatem również w tych słowach biskupa dostrzec wzmiankowany już element, ważny z punktu widzenia moralnej biografii św. Augustyna: związanie się z jedną kobietą stanowiło dla niego pewne wyrzeczenie i moralny hamulec, którego nie stosowało wielu jemu współczesnych.

Wprowadza następnie ważne rozróżnienie między prawdziwym - jak to nazywa - małżeństwem i małżeństwem zawieranym z namiętności. To pierwsze zawierane jest w celu wzbudzenia potomstwa, drugie natomiast jedynie dla zaspokojenia potrzeb seksualnych. Również i z tego drugiego mogą rodzić się dzieci, ale zwykle nie są one chciane. W przypadku związku św. Augustyna $\mathrm{z}$ kobietą bezimienną, dziecko narodziło się niechciane, ale zostało przez rodziców pokochane.

6. Culpa czy poena? W analizowanym tekście mamy istotne określenie z punktu widzenia moralnej oceny czternastoletniej relacji św. Augustyna z kobietą bezimienną: pactum libidinosi amoris, czyli związek zawarty dla zaspokojenia namiętności. Kluczowe znaczenie dla bardzo negatywnego spojrzenia na historię z bezimienną oraz dla przyznania się do własnej culpa odgrywa słowo libido albo libidinosus, używane przez pisarza, by wskazać na namiętności, jakim człowiek może ulegać w swoim życiu.

W innym miejscu Wyznań św. Augustyn umieszcza libido wśród najcięższych grzechów:

„Takie są główne rodzaje grzechów. Wynikają one z żądzy (libido) władzy, z ciekawości i ze zmysłowości - albo z jednej z tych skłonności, albo $\mathrm{z}$ dwóch, albo ze wszystkich trzech naraz"18.

Jeszcze w innym tekście autor Wyznań ma odwagę szczerze powiedzieć, że w owym czasie był niewolnikiem żądzy (libidinis servus):

„Kobietę, z którą dotychczas żyłem, oderwano od mego boku, gdyż była to przeszkoda na drodze do małżeństwa. Ponieważ moje serce mocno do

${ }^{16}$ Tamże XIII 7, 8, NBA 1, 456: „Immunditia spiritus nostri defluens interius amore curarum”, thum. Kubiak, s. 416.

${ }^{17}$ Por. tamże I 18, 28, NBA 1, 30, tłum. Kubiak, s. 49.

${ }^{18}$ Tamże III 8, 16, NBA 1, 72: „Haec sunt capita iniquitatis, quae pullulant principandi et spectandi et sentiendi libidine aut una aut duabus earum aut simul omnibus”, thum. Kubiak, s. 85. 
niej przywarło, teraz wyszarpnięto w nim ranę, która broczyła krwią obfitą. Kobieta wróciła do Afryki, ślubując Ci, że nigdy się nie odda żadnemu innemu mężczyźnie, a ze mną zostawiła syna naturalnego, jakiego mi urodziła. Byłem zbyt słaby, aby naśladować ten wzór, jaki mi dała niewiasta. Niecierpliwiło mnie dwuletnie oczekiwanie na narzeczoną, bo nie tyle ożywiało mnie pragnienie małżeństwa, ile byłem po prostu niewolnikiem żądzy (libidinis ser$v u s)$. Postarałem się więc o inną kobietę i żyłem z nią bez małżeństwa"19.

Z przytoczonego tekstu dowiadujemy się jeszcze o kilku innych sprawach dotyczących relacji św. Augustyna z kobietą bezimienną, które mają związek z interesującym nas tematem. Najpierw zatem biskup podaje nam, że postanowiła ona wrócić do Afryki i że złożyła swego rodzaju ślub dochowania mu wierności. Niektórzy, również na podstawie tego zdania, uważają, że zaczęła prowadzić tryb życia osoby konsekrowanej, albo nawet, że wstąpiła do wspólnoty zakonnej. Z braku dowodów w tym temacie, pozostajemy jedynie na poziomie przypuszczeń. Nie wiemy też, czy kiedykolwiek dane było św. Augustynowi i bezimiennej spotkać się ponownie.

W tekście mamy też informację, że św. Augustyn, oczekując na legalne małżeństwo z wybraną - być może przez św. Monikę - narzeczoną, której do zawarcia legalnego małżeństwa brakowało dwóch lat, znalazł sobie jeszcze inną konkubinę. Teraz pisze o tym z wielkim smutkiem, zdając sobie sprawę ze swoich moralnych upadków i mając w pamięci szlachetną postawę kobiety bezimiennej.

Pisarz nie ma wątpliwości co do własnej winy (culpa) w relacjach z kobietami i popełnianego zła wobec siebie samego i wobec nich, co wywoływało w nim już wtedy ogromne cierpienie:

„Oznaczało to, że choroba mojej duszy jeszcze się wzmoże i umocniona nieprzerwanym przyzwyczajeniem przetrwa aż do pożycia z żoną. A rana, jaką spowodowało oderwanie ode mnie mojej poprzedniej towarzyszki, wcale się nie goiła. Po okresie straszliwego bólu zaczęła ropieć i chociaż wtedy ból jakby stępiał, cierpiałem tym rozpaczliwiej"20.

Interesuje nas teraz, czy św. Augustyn dostrzegał w tamtych latach również zło jako poena, czyli zło doznawane na skutek sprawiedliwego wyroku

${ }^{19}$ Tamże VI 15, 25, NBA 1, 174: „Et avulsa a latere meo tamquam impedimento coniugii cum qua cubare solitus eram, cor, ubi adhaerebat, concisum et vulneratum mihi erat et trahebat sanguinem. Et illa in Africam redierat vovens tibi alium se virum nescituram relicto apud me naturali ex illa filio meo. At ego infelix nec feminae imitator, dilationis impatiens, tamquam post biennium accepturus eam quam petebam, quia non amator coniugii sed libidinis servus eram, procuravi aliam, non utique coniugem", tłum. Kubiak, s. 175.

${ }^{20}$ Tamże VI 15, 25, NBA 1, 174: „Quo tamquam sustentaretur et perduceretur vel integer vel auctior morbus animae meae satellitio perdurantis consuetudinis in regum uxorium. Nec sanabatur vulnus illud meum, quod prioris praecisione factum erat, sed post fervorem doloremque acerrimum putrescebat et quasi frigidius, sed desperatius dolebat", thum. Kubiak, s. 173. 
boskiego? Żeby odpowiedzieć na to pytanie, trzeba najpierw, tytułem wprowadzenia, zauważyć, że w koncepcji św. Augustyna grzech powoduje związane z nim cierpienie i może być powodem jakiejś kary dodatkowej według wyroku boskiego. W pierwszym przypadku przyczyna i konsekwencje grzechu mogą być rozpoznane (np. cierpienie duchowe po wyrządzonym złu), w drugim natomiast znane są jedynie Bogu (np. jakaś klęska żywiołowa może, ale nie musi być konsekwencją konkretnych grzechów społeczności). Poena jest jednocześnie konsekwencją grzechu i karą za ten grzech ${ }^{21}$.

Czytając i analizując odnośne testy Wyznań, łatwo zauważyć, że św. Augustyn nie oskarża swojej pierwszej towarzyszki; raczej wychwala jej zachowanie i szlachetność, i szczerze się przyznaje do tego, że był za słaby, aby naśladować jej wzór. Św. Augustyn nie mówi w odniesieniu do relacji z kobietą bezimienną o karze (poena) ze strony Boga. Raczej ukazuje Jego miłosierdzie i pomoc:

„W miarę jak się pogłębiała moja niedola, Ty byłeś coraz bliżej mnie. Chociaż o tym nie wiedziałem, już wyciągałeś rękę, aby mnie z bagna wydobyć i obmyć"22.

Biorąc pod uwagę rozróżnienie wprowadzone przez św. Augustyna na zło czynione, rozumiane jako konsekwencja złego wyboru (culpa), oraz zło doznawane jako skutek sprawiedliwego wyroku boskiego (poena), które to rozróżnienie pisarz stosuje $\mathrm{w}$ wielu przypadkach analizując przyczyny i wymiary zła, w odniesieniu do swojej relacji z bezimienną podciąga niemal wszystko pod culpa; odnosi się wrażenie jakby pisarz chciał wziąć całą odpowiedzialność moralną na samego siebie. Tego typu postawa pozwala św. Augustynowi ukazać w jeszcze większym stopniu miłosierdzie działającego Boga, który zbliżał się do niego coraz bardziej w miarę jak rosło jego cierpienie, wynikające z popełnianego zła.

${ }^{21}$ Por. T. Breyfogle, Pena, w: Agostino. Dizionario enciclopedico, s. 1089: „Nel primo caso la causa e l'effetto del peccato e della pena possono essere discernibili, mentre nel secondo il peccato specifico può essere sconosciuto (eccetto a Dio) [...] La pena è insieme una conseguenza del peccato e una punizione per esso".

${ }^{22}$ Augustinus, Confessiones VI 16, 26, NBA 1, 174: „Ego fiebam miserior et tu propinquior. Aderat iam iamque dextera tua raptura me de caeno et ablutura, et ignorabam”, thum. Kubiak, s. 173. 


\title{
ID NON CULPAM, SED POENAM ESSE IUDICABAM \\ (CONFESSIONS VII 3, 5): SOME QUESTIONS AND REFLECTIONS \\ OF SAINT AUGUSTINE ON THE ORIGIN OF EVIL
}

\begin{abstract}
(Summary)
In light of the distinction Saint Augustine makes between a committed evil, understood as the result of a mistake in choosing (culpa), and a suffered evil, described as the effect of a just divine judgment (poena) - a distinction he makes in several texts dealing with the origin of evil - I analyze Augustine's reflections in the Confessions on his relationship with the unnamed women. He calls the relationship a pactum libidinosi amoris, that is, one aimed at satisfying the passions. The negative moral judgment he passes on this stage of his life is expressed with particular poignancy by the word libido/libidinosus, indicating the passions to which man submits at times. Looking back at his affair with the unnamed woman, he considers the evil committed a culpa; hence one has the impression that he wanted to place the moral responsibility of the evil committed upon himself, thus giving greater witness to the goodness of the merciful God who revealed to him gradually the truth concerning the various phases of his spiritual journey and the pain experienced along the way.
\end{abstract}

Słowa kluczowe: culpa, poena, źródło zła, zło czynione, zło doznawane, wolna wola, osąd boski, miłość lubieżna, pakt małżeński.

Key words: culpa, poena, the origin of evil, evil done (to one), evil endured, free will, divine judgement, libidinous love, the marital covenant. 